\title{
EL COMERCIO ATLÁNTICO DE RÍO DE LA PLATA, 1680-1778. EL CIRCUITO LEGAL ESPAÑOL. LAS FUENTES UTILIZADAS Y SU TRATAMIENTO
}

\author{
Fernando Jumar*
}

\section{PRESENTACIÓN}

$\mathrm{E}$

n este texto me propongo presentar la principal fuente que utilicé para obtener las cifras del comercio ultramarino legal español en Río de la Plata entre 1680 y 1778, cómo fue explotada y algunos de los resultados obtenidos. Se trata de los registros de navíos. ${ }^{1}$ Los resultados de la investigación, que comprendía también otros aspectos del comercio ultramarino rioplatense, se tradujeron en una tesis de doctorado defendida en el año $2000 \mathrm{y}$ publicada en 2002.

Mi objetivo era estudiar el comercio rioplatense durante el siglo XVIII, en un proyecto inicialmente muy ambicioso (como lo es el de todo doctorando en sus orígenes), en el cual me proponía no sólo conocer el comercio ultramarino de Río de la Plata (tanto legal como ilegal), sino también sus vinculaciones con los mercados interiores sin olvidar el mundo de la producción. El resultado final cubre solamente el primero de los asuntos y las preguntas que aún me quedan sin responder seguramente me darán trabajo por el resto de mi vida útil como historiador.

* Universidad Nacional de Tres de Febrero, Universidad Argentina de la Empresa, Universidad Nacional de La Plata, Argentina. Correo electrónico: <fjumar@uade.edu.ar>.

' Además de los registros de navíos, recurrí tanto en los archivos españoles como argentinos a otras fuentes, tales como las cartas-cuenta de los oficiales reales, procesos judiciales, testamentarias, correspondencia oficial y privada, disposiciones reales, etc. Es decir, la "bateria" habitual de fuentes utilizadas por quienquiera que desee abordar el estudio del comercio colonial y de los actores participantes. 
No he sido el primero en recurrir a los registros de navíos para estudiar el tráfico de la Carrera de Indias, ${ }^{2}$ aunque creo que la forma en que exploté la fuente es original. Las críticas que hacía Michel Morineau ${ }^{3}$ al trabajo de Antonio García-Baquero González ${ }^{4}$ me convencieron y me condujeron a pensar y repensar sobre el buen empleo de las fuentes tradicionales de los archivos hispánicos relacionadas con el comercio legal español. ${ }^{5}$ Ello me condujo a lo que me parece ser una verdadera innovación en la manera de utilizarlas. No sólo no iba a utilizar los resúmenes de las cargazones sino los totales surgidos de la suma de miles y miles de partidas de registro contenidas en los registros de los navíos que circularon al interior del sistema legal español. También me doté de los medios necesarios para tornar útiles los datos nominativos contenidos en las partidas. Así, no sólo podría conocer los totales sino también llegar hasta el nivel de los individuos que participaron en el tráfico, y analizar el alcance de su participación.

Al mismo tiempo, mi punto de vista, centrado en Río de la Plata, ${ }^{6}$ me llevó a buscar los archivos de Colônia do Sacramento en Brasil y Portugal; desgraciadamente, no encontré otra cosa que briznas de información, pero que confirman que el enfoque elegido es adecuado.

Las eternas alusiones al contrabando francés e inglés hicieron que fuera a Francia para encontrar la pista de las empresas malvinas, en tanto que la lectura de la tesis de Victoria Ann Sorsby (1975) que trata del comercio inglés bajo el asiento de esclavos me mostró que en los archivos ingleses no había mucho que encontrar y no pude justificar una estadía en Londres.

${ }^{2}$ El trabajo más antiguo que conozco que utiliza los registros de navíos para acercarse al tráfico ultramarino de Río de la Plata es del historiador argentino Torre, "Navíos", 1963.

${ }^{3}$ Morineau, Incroyables, 1985.

${ }^{4}$ García-Baquero, Cádiz, 1976.

${ }^{5} \mathrm{El}$ mismo García-Baquero recogió el guante lanzado por Morineau y también dejó de lado las relaciones de la Contratación para enfrentar los registros, publicando sus resultados en 1996. Asimismo, Arazola, Hombres, 1998, decidió utilizar los registros de navíos en su tesis de doctorado, aunque, en mi parecer, con algunas deficiencias metodológicas. Finalmente, Moutoukias también recurrió a los registros en más de una oportunidad, véanse "Rio", 1983, y "Crecimiento", 1996, pero creo que los totales que presenta no surgen de la suma de las partidas de registro sino de los resúmenes de las cargas que en ellos aparecen. Comentar cada uno de estos trabajos y comparar sus resultados con los que obtuve sería tema de otro artículo, por lo que me permito remitir a otro texto en que ya hice un primer acercamiento a la cuestión: Jumar, Commerce, 2002, pp. 402-437.

${ }^{6}$ Ese punto de vista me llevó a comprender que Río de la Plata durante la dominación hispana no constituía una frontera entre sus dos bandas y que existió un complejo portuario formado por las ciudades-puerto (Buenos Aires, Colônia do Sacramento y Montevideo) y un número indefinido e indefinible de desembarcaderos ad-hoc sobre la costa bonaerense. Así, el "comercio rioplatense" no se limita al estudio del movimiento del puerto de Buenos Aires, a pesar de que en ciertos aspectos la capital administrativa de los españoles en Río de la Plata haya desempeñado el papel de articulador de ese complejo portuario. El complejo portuario rioplatense, su existencia, constitución y modalidades de funcionamiento constituyen el tema del capítulo II de Jumar, Commerce, 2002, t. I, cap. II, "Le complexe portuaire rioplatense", pp. 94-179. 
El cruzamiento de todas estas fuentes, aunque a veces no den la palabra a los rioplatenses, además de obtener cifras para las exportaciones de Río de la Plata entre 1680 y 1778 me permitió aprehender indirectamente sus expectativas, sus comportamientos, sus estrategias y esa capacidad que tuvieron para "ser-juntos", para poder hacer de Río de la Plata una de las terminales de las rutas del comercio atlántico.

\section{LOS REGISTROS DE NAVIOOS}

Los registros de navíos fueron la fuente principal utilizada para obtener el detalle de las cargazones de las embarcaciones que circularon por dentro del sistema legal español y también permitieron conocer a los interesados en ellas. La navegación legal española en dirección de Río de la Plata estaba compuesta por los navíos de registro (desde 1622), los avisos, las fragatas-correo (desde 1768) y los navíos del servicio real. Entre dichas embarcaciones se incluyen tanto las que salieron de Europa con las debidas licencias como las que las autoridades españolas residentes en Río de la Plata incorporaron al sistema de comercio oficial; de todas éstas ignoro si las cargas registradas llegaron a Europa. Finalmente, aunque también pertenecen al circuito legal, las embarcaciones de las compañías esclavistas francesa e inglesa no serán consideradas aquí porque las fuentes utilizadas para conocer sus embarques fueron otras, así como por considerar las características peculiares de su inserción en dicho circuito legal.

A fin de simplificar este texto, me concentraré en los registros de navíos pertenecientes a los navíos de registro, que engloban las peculiaridades que presentan los de las fragatas-correo y los de los navíos del servicio real. Bajo la identificación de registros de navios, tanto en los archivos españoles como en los argentinos, se encuentran los legajos de documentos que reúnen todos los papeles relacionados con una expedición comercial. En el Archivo General de la Nación de Buenos Aires (en adelante AGN) cada navío cuenta con un expediente, en tanto que en el Archivo General de Indias en Sevilla (en adelante AGI) la información está separada en dos expedientes, uno relacionado con el viaje de España a América (registro de ida) y el otro con el de retorno (registro de tornaviaje, de regreso o de venida). Así, el registro se abre con la real cédula que concede la licencia de navegación y se termina con la cancelación de las fianzas de maestraje, es decir, con la anulación de las garantías dadas antes de la salida de España por quien iba a ser el responsable de las cargas transportadas a la ida y al regreso.

La composición y la forma de los documentos incluidos en cada expediente cambiaron a lo largo del tiempo. Durante la guerra de Sucesión comienzan a tomar la forma que se consolidará a partir de 1720. El conocido Proyecto... de ese año y las modificaciones menores que lo siguieron dieron el marco legal a 
la navegación comercial hasta 1778. En cuanto a lo que interesa aquí, en 1720 se restablece la obligación de la elaboración de los registros, que había sido dejada de lado en 1660, y se consolida un modo de confección de los registros de ida y de venida que adquieren definitivamente la forma de listas numeradas en la que cada embarque es detallado. ${ }^{7}$

\section{Los registro de ida}

Como se señaló, los registros de ida se abren con la Real Cédula que concedía el derecho de navegar hacia América. Luego siguen papeles relacionados con los trámites seguidos por los interesados en la obtención de la licencia y el establecimiento de la fianza de maestraje dada por quien era designado en tanto que maestre de plata por los armadores de la expedición.

Después aparece el registro de ida propiamente dicho, es decir, la lista numerada que servía para consignar los bultos de bienes enviados a Río de la Plata con identificación de los remitentes (los cargadores), de las personas "por cuenta y riesgo" de quien navegaba la carga y los destinatarios en Río de la Plata. Antes de 1720, este registro está por lo general ausente, como se señaló. En el mejor de los casos, entre 1660 y 1720 para obtener informaciones sobre las cargas de los viajes de ida se cuenta con indicaciones sobre el valor total a precios de compra en España, gracias a las condiciones de la concesión de la licencia o las certificaciones relacionadas con el pago de derechos. A partir de 1720 se generaliza el palmeo, practicado de modo intermitente desde fines del siglo XVI, lo que trae como resultado para el investigador que estos registros de ida poco sirven para conocer el detalle de las cargas, como es sabido. Sólo quedan visibles unos cuantos bienes excluidos del palmeo, como los productos agrícolas españoles o las ferreterías. ${ }^{8}$

De este modo, además de conocer en detalle las cargas excluidas del palmeo, lo máximo que se podría obtener de estos registros de ida es conocer a los actores participantes en el tráfico y la cantidad de toneladas cubo de mercaderías enviadas. Este último dato no me pareció revelador de nada, y renuncié a explotar con profundidad esta fuente. María Jesús Arazola Corvera ${ }^{9}$ opinó de modo diferente al hacer su investigación, y centra una parte importante de su estudio sobre el comercio en dirección de Río de la Plata entre 1737 y 1757 sobre estos registros, pero los resultados que obtuvo confirman grosso modo mi primera impresión. Para conocer lo que era comercializado en Río de la

\footnotetext{
${ }^{7}$ La única variación de importancia que encontré es que a partir de 1760 comienzan a realizarse registros separados para los caudales y para los frutos.

${ }^{8}$ García-Baquero, Cádiz, 1976, t. I, pp. 197-201, presenta la evolución del sistema impositivo en dirección del palmeo y el listado de bienes excluidos del mismo en 1720 .

${ }^{9}$ Arazola, Hombres, 1998.
} 
Plata esta historiadora española debió recurrir, como yo, a los raros casos en los cuales toda la carga de un navío era conocida en detalle. Sin embargo, hay que precisar que no se trata de navíos de registro "normales", sino de licencias especiales concedidas a comerciantes portugueses, lo que puede conllevar una composición de las cargas de ida diferente de la que era corriente en los navíos españoles, que son la mayoría.

Finalmente, los registros de ida cuentan con otros papeles, tales como las diferentes visitas realizadas antes de la salida, el arqueo, el registro de la marinería y el de los pasajeros. El registro de ida se cerraba con la visita de salida, la última inspección realizada antes de que el navío zarpase, cuyo objetivo era constatar que no se transportaba nada fuera de registro. Luego de ello, se sacaba una copia de todo el documento (el original quedaba en la contratación y es ahora el documento disponible en el AGI), se la sellaba y la primera obligación del maestre al llegar a su destino era entregarla a las autoridades. Este documento era la prueba de que se trataba de una expedición autorizada y con la noticia de su presentación se abre el registro de tornaviaje. Esta copia del registro de ida más los originales de los documentos generados, en mi caso, en Río de la Plata desde la llegada del navío y hasta su salida, constituyen los expedientes conservados en el AGN, y una copia de estos papeles se encuentra en Sevilla.

\section{Los registros de tornaviaje}

Una vez reconocido el derecho de un navío de entrar a puerto, se realizaba la visita de entrada: la inspección cuyo objetivo era constatar que no había cargas fuera de registro; de algún modo, se trataba de la duplicación de la visita de salida realizada en España antes de la partida.

Para la realización de estas inspecciones, el gobernador de Buenos Aires nombraba por lo general a tres personas que, acompañadas por algunos soldados, debían recorrer todo el navío y revisar cada bulto, controlando con el registro de ida la numeración e identificación de cada uno de ellos con el objetivo de verificar que no hubiera nada más que lo que estaba registrado. También debía verificarse que las personas a bordo correspondieran a la tripulación y a los pasajeros registrados. Por lo general se encargaban de realizar la visita de entrada los oficiales de la Reales Cajas, aunque a veces la misión fue encomendada al sargento mayor de Buenos Aires o a los alcaldes del Cabildo.

Una vez terminada sin escollos la visita de entrada, comenzaba la descarga del navío. Hasta fines del siglo XIX, Buenos Aires no tuvo verdaderas instalaciones portuarias y las embarcaciones, según su calado, debían echar anclas más o menos lejos de la orilla. Hombres y bienes debían llegar a la costa sobre carros de dos ruedas que entraban en el río. Avanzado el siglo XVIII, el puerto de Montevideo comienza a ser utilizado para la llegada de las embarcaciones 
ultramarinas, y su carga se transfería a la otra orilla por medio de embarcaciones medianas y pequeñas.

La etapa siguiente era la visita de fondeo, cuyo objetivo era verificar que el navío había sido totalmente descargado para evitar posibles transbordos de bienes de origen ilegal (no hay que olvidar la presencia portuguesa en Colonia del Sacramento). En la práctica, esta visita siempre era retardada, siempre quedaba algo por descargar y en general se realizaba solamente cuando los maestres deseaban comenzar a constituir la carga de regreso a España. Mientras tanto, y con un estatus legal confuso, las embarcaciones iban y venían entre los diferentes lugares de fondeo que ofrecía el río para protegerse de pamperos $\mathrm{y}$ sudestadas ${ }^{10}$ (y seguramente para reaprovisionar las bodegas).

La continuación de los expedientes hasta el establecimiento del registro de regreso propiamente dicho varía de un navío al otro. La única regla que pude establecer en cuanto a los documentos conservados es que allí se encuentra todo lo que las autoridades consideraron necesario agregar en previsión de la copia que debía hacerse para ser enviada a España junto con la embarcación. En la mayoría de los casos se trata de documentos que reflejan situaciones conflictivas, aunque también aparecen listados de gastos y otras informaciones sobre la permanencia del navío en el río.

Cuando el maestre deseaba comenzar a constituir la carga de regreso, solicitaba al gobernador la autorización para abrir el registro de tornaviaje, lo que yo llamo el registro de regreso propiamente dicho. Este documento contiene la mayor parte de la carga legalmente declarada para ser llevada a Europa y su forma es la de una lista numerada que señala cada uno de los embarques con identificación de los interesados. Generalmente la salida de las naves se postergaba una y otra vez, lo que generó que en algunos casos se abriera más de un registro para dar cabida a nuevos pedidos de licencia de embarque. Volveré sobre este documento más adelante. Otras cargas legales figuran en lo que llamo partidas aisladas (permisos de embarque, por lo general de metales preciosos, autorizados una vez cerrado el último registro y cuando el navío estaba pronto a zarpar) y en el registro de pasajeros.

Este último, además de identificar al pasajero (y muy raramente la causa del viaje) contiene lo que el individuo transportaba consigo como equipaje y los metales preciosos que no había confiado al maestre para ser insertos en el registro. En general se trata de algunos cientos de pesos por pasajero (para

${ }^{10}$ La navegación en Río de la Plata era y es peligrosa debido a fuertes vientos que se desatan inesperadamente y que durante el periodo colonial causaron más de un naufragio. Uno de los más célebres es el del navío portugués Nuestra Señora de la Luz, estudiado por Apolant, Crónica, 1968, y que en años recientes fue objeto de una operación de rescate realizada por el buscador de tesoros Rubén Collado <http://www.diabolik.com.ar/collado/principal.htm> [Consulta: 22 de junio 2003.] 
hacer frente a los gastos de una arribada forzosa o la llegada a España) y plata labrada (por lo general, vajilla).

Una vez que el o los registros estaban cerrados definitivamente y cuando el navío verdaderamente estaba por zarpar, se realizaba la última inspección, la visita de salida. Esta visita era mucho más expeditiva que la de entrada, porque, en teoría, había sido ya controlada la carga de regreso a España: los cueros y otros frutos a medida que eran embarcados y los metales preciosos cuando eran reunidos por el maestre, puestos en cofres y subidos a bordo (ésta era la última operación antes de la visita de salida, y en muchos casos se realizaba al mismo tiempo que ésta). Antes o después de la visita de salida aparece en el expediente el registro de pliegos: la lista de correspondencia, oficial y privada, confiada al maestre.

Independientemente de los registros de regreso propiamente dichos, el conjunto de documentos generados en Río de la Plata durante la estadía de los navíos brinda informaciones que raramente permiten conocer las cargas de ida o su negociación. Algunos expedientes contienen datos relacionados con los gastos de todo tipo que generaban las habitualmente largas estadas en Río de la Plata, así como los que se relacionan con el aprovisionamiento para el viaje de retorno. Con esa información se puede intentar conocer cómo la navegación ultramarina dinamizaba la economía local y sus efectos repercutían en todas las esferas de la población.

En otro orden de problemas, las expectativas que tenía en torno a las diferentes visitas no se vieron satisfechas. Se podría esperar que sirvieran para develar algunos contrabandos, lo que hubiera generado decomisos, inculpaciones y procesos; es decir, que esperaba que fueran fuentes que habrían permitido entrar en el mundo del fraude. Pero sólo en una oportunidad una visita de entrada trajo como consecuencia el decomiso de diez esclavos. ${ }^{11}$ En el resto de los 98 años analizados, ese caso es la excepción que confirma la regla: según las visitas, el fraude no existió en la Carrera de Indias, o al menos en la de Buenos Aires. Evidentemente, la corrupción comenzaba con la llegada misma de los navíos.

Sin embargo, no estoy convencido de que todos los funcionarios hayan sido proclives a la aceptación de regalos que tenían como consecuencia la puesta en suspenso o la atenuación de las disposiciones reales sobre el comercio. Sería una manera muy simplista de ver las cosas que llevaría a clichés tan simples como la "leyenda negra" y la "leyenda rosa" de la conquista del continente. Pero es una afirmación corriente que todos los navíos transportaban bienes fuera de registro, además de las pacotillas de la tripulación que estaban toleradas (cuando no eran excesivas).

\footnotetext{
"Se trata del aviso "San Zenón", los esclavos fueron embarcados en fraude en Río de Janeiro.
} 
Hay dos explicaciones posibles además de la corrupción -que existió, no pretendo afirmar lo contrario- para la inexistencia de molestos descubrimientos durante las visitas.

La primera es que los navíos no transportaban bienes fuera de registro. Idea que no se sostiene, aunque dadas las peculiaridades del complejo portuario rioplatense es posible que el fraude al interior del circuito legal español no fuera tan importante como en otros destinos de la Carrera. Colonia del Sacramento era el sitio para ese tipo de actividades.

La segunda es que las visitas no se llevaban a cabo realmente o que no dejaban de ser un puro formalismo. Esta posibilidad me parece más probable. Las personas encargadas de hacer la visita de entrada, por falta de "amor al real servicio", no se tomarían la molestia de cumplir adecuadamente su trabajo y no veían nada anormal en las bodegas y entrepuentes de los navíos simplemente porque no se molestaban en visitarlos y menos aún en confrontar lo que allí se encontraba con el registro de ida. Sólo hay que intentar imaginar a los muy respetables oficiales reales metidos en las bodegas de los barcos, en medio de las ratas, saltando entre los fardos y moviéndolos para encontrar números y sellos. $\mathrm{O}$ en la visita de salida, buscando escondites para los metales preciosos o recontando en promedio unos 10000 cueros. Todo ello habría sido poco digno de ellos.

Gracias a algunas informaciones se puede ver que la visita se reducía a una buena comida servida a bordo. ${ }^{12}$ También sería simple caer en los clichés de la holgazanería, la desidia o la falta de eficacia de los españoles como lo es caer en el de la corrupción, pero un razonable equilibrio entre todos ellos debe poder ayudar a explicar los buenos resultados de las visitas según el punto de vista de todos, menos de la corona. Así, las visitas, de entrada y de salida, se cierran con una frase del estilo "el navío no transporta otra cosa que lo que figura en el registro".

En la visita de salida se debía insertar un resumen de la carga, pero raramente se encuentra. Se lo puede sustituir con los resúmenes redactados por los maestres al momento de solicitar la inspección o cuando se anuncia el cierre del registro. Estos resúmenes raramente coinciden con mis resultados, fruto de la suma de las partidas de registro. Los resúmenes dan cifras a veces superiores, a veces inferiores a las obtenidas, $y$ en algunos casos las diferencias son importantes. No encontré una explicación realmente satisfactoria para estas diferencias. Salvo cuando se dispone de resúmenes inscritos en la visita de salida,

12 El administrador del aviso "Nuestra Señora de las Tres Fuentes", llegado a Buenos Aires en julio de 1760, hizo comprar para la visita de entrada: doce gallinas, ocho pollos, pichones de paloma, dos pavos, cuatro corderos, legumbres, pan fresco y un pastel. El gasto fue de 30 pesos 4 reales. Además, mandó abrir algunas buenas botellas de vino transportadas a bordo y completar la compra con alimentos que había en su despensa. Archivo General de la Nación (en adelante AGN), IX-32-82, Hacienda 1761-1767, exp. 55. 
los resúmenes de los maestres pueden presentar sólo una parte de la carga. En efecto, en algunos casos, encontré que después del anuncio formal del cierre del registro había algunos folios con nuevos pedidos de licencia de embarque o pequeños registros de regreso adicionales, sin nuevos resúmenes hechos por los maestres. Esto explicaría las diferencias en estos casos en los que las sumas de los registros de regreso son superiores a las de los resúmenes. Cuando son inferiores, no tengo otra explicación que la desaparición del expediente de los papeles que demostrarían la presencia de embarques hechos con posterioridad al cierre del registro.

\section{Los registros de regreso propiamente dichos}

Como ya se mencionó, desde que el maestre de plata anunciaba oficialmente la preparación del viaje de regreso solicitaba la autorización de abrir el registro de tornaviaje. Cuando se trata de navíos del servicio real, este registro se inicia con la designación por el gobernador de Buenos Aires de un maestre. En este último caso, los navíos no tienen registro de ida ya que no podían transportar mercaderías en sus viajes de ida, pero podían tomar cargas a flete en su regreso, sin dudas, un modo de rentabilización del viaje para la Real Hacienda. ${ }^{13}$

Los registros de regreso tienen la forma siguiente: una primera parte donde el navío y el maestre son identificados, ${ }^{14}$ luego sigue una lista numerada de partidas de registro, es decir, de cada uno de los componentes de la carga registrada. ${ }^{15}$ Una vez terminado el listado, el registro se cierra con una serie de fórmulas legales en las que el maestre se compromete a entregar lo registrado a sus destinatarios. ${ }^{16}$

${ }^{13}$ Esta peculiaridad de los navíos del Real Servicio permite elaborar algunas hipótesis en torno a la accesibilidad del comercio ultramarino para quienquiera que quisiese emprender la aventura. De hecho, estos navíos en sus regresos a España ofrecían una suerte de sistema público de transportes, abierto al primero que llegaba solicitando espacio en las bodegas $y$, tal vez, tornaba menos necesaria la pertenencia a alguna de las redes de relaciones estructuradas en torno a los sobrecargos de los navíos privados. Al mismo tiempo, el gobernador de Buenos Aires, al designar como maestre a alguno de los comerciantes locales, le abría las puertas del tráfico ultramarino en un papel distinto del de agente de casas metropolitanas.

${ }^{14}$ Por ejemplo: "Registró don Juan Bauptista de Escarza, capitán y maestre del navío nombrado El Vigilante, que con registro de ropas, vino a este puerto, y está próximo, para hacer su tornaviaje al de Cádiz, los caudales en plata, oro y frutos que abajo se expresarán, de cuenta de S. M. y de particulares, que sus riesgos y consignaciones son a saber..." Archivo General de Indias (en adelante AGI), Contratación 2741. Registro del navío El Vigilante, 1761.

${ }^{15}$ Un ejemplo de partida de registro: "72. De don Domingo de Basavilbaso 300 pesos plata doble, de cuenta y riesgo de don Juan Thomás de Segada, para entregar a don Joachin Muñoz y Perez, vecino de Cádiz, ausente a su poder." AGI, Contratación 2741. Registro del navío El Vigilante, 1761. Este navío contó con dos registros de tornaviaje. El primero cerrado el 2 de junio de 1761 (con 190 partidas) y el segundo el 30 de junio del mismo año (con 22 partidas).

16 "De todos los cuales dichos caudales en plata, oro y frutos, se dio por recibido, y entregado a su satisfacción, y contento debajo de cubierta del expresado navío, el referido don Juan Bauptista de 
La lista numerada, que constituye la parte central del documento, retoma cada uno de los pedidos de licencia de embarque dirigidos al gobernador por el maestre de plata, que a su vez retoman los pedidos dirigidos al maestre por las personas que querían embarcar algo en el navío. Es decir, que en el mejor de los casos, se dispone de tres series de documentos para reconstituir la carga legal del navío.

El camino que conducía a la redacción final del registro comienza cuando el maestre de plata se dirige al gobernador anunciándole que estaba presto a partir -aunque podía pasar más de un año entre este momento y la salida efectiva del navío. Acto seguido, el gobernador publicaba un bando anunciando la apertura del registro con la fecha de cierre del mismo, que coincidía con la estipulada por el maestre para la partida. Muchos navíos no salían en las fechas estipuladas, lo que conlleva la apertura de más de un registro de regreso. Al procesar la información los tratamos como si fuera de un solo registro para facilitar la obtención del total por barco. ${ }^{17}$

A la hora de interpretar esos datos, una primera observación que se debe realizar es que en la mayoría de los casos es imposible saber a qué corresponden los envíos registrados; todas las posibilidades imaginables son plausibles. Una cosa es segura, de las partidas de registro se desprende que la carga de un barco no es el retorno de la carga transportada a la ida. ${ }^{18}$ En el registro se mezcla parte de esos retornos con otros tipos de envíos, entre los que figuran retornos de expediciones comerciales anteriores. Las partidas permiten conocer otros envíos. Se puede estar ante un habitante de Buenos Aires que envía a España metales preciosos of frutos para que el destinatario se los devuelva convertidos en mercaderías; en este caso, los comerciantes locales, en lugar de actuar en tanto que agentes de comerciantes residentes en España, estarían invirtiendo los papeles tradicionalmente adjudicados a cada parte. Igualmente puede tratarse de envíos a España de partes de herencia, de donaciones piadosas, de dotes para hijas o hermanas, de sumas destinadas para el mantenimiento de la familia. Ciertamente, los metales preciosos involucrados en estos últimos casos provenían mayoritariamente del comercio, pero también de otras fuentes (ahorros sobre salarios, por ejemplo). En fin, se puede simplemente estar

Escarza, y otorgó recibo de ellos en forma y conforme a derecho [...] y se obligó con su persona y bienes habidos y por haber, a que llevándole Dios nuestro Señor a salvamento con el citado navío al puerto de Cádiz, u otro cualquiera de los de Castilla, donde se diere por cumplido su registro, hará su puntual entrega a las personas a quienes van dirigidos según las partidas de registro aquí insertas a cuyo cumplimiento se obligó en forma y conforme a derecho. Y así lo otorgó, y firmó siendo testigos..." AGI, Contratación 2741. Registro del navío El Vigilante, 1761.

${ }^{17}$ Concretamente, esta operación la única modificación que introduce en la información original es el número de orden asignado a las partidas de los registros suplementarios.

${ }_{18}$ De hecho, como es sabido, la negociación de un cargamento duraba más que la estada del mismo en América y los envíos del producto se escalonaban a lo largo del tiempo. 
ante el envío a España de sumas correspondientes a seguros, para saldar préstamos a riesgo de mar o para ser utilizadas como regalos destinados a aumentar las posibilidades que ganar un proceso en curso. En síntesis, se puede saber lo que cada navío transportó a España, pero sólo se pueden elaborar conjeturas sobre qué representan esos envíos, aunque no es temerario aventurar que la mayor parte de esas cargas refleja actividades comerciales. Independientemente de ello, esos totales se revelan como la forma más segura de conocer el tráfico legal, e inclusive son la fuente de información, según Michel Morineau, de sus gazettes hollandaises. ${ }^{19}$

Pero más allá de la obtención de los totales por embarcación, las partidas de registro brindan la posibilidad de acercarse a los actores del tráfico, con informaciones que varían según el detalle con el que fue redactada la lista. ${ }^{20}$

Ahora bien, no siempre los registros pudieron ser utilizados en su totalidad. Sólo basta con que un par de hojas esté dañado para saber que el total a obtener sería menor que el real. Afortunadamente estos casos se vieron reducidos al mínimo por haber trabajado en los archivos de Sevilla y Buenos Aires, lo que permitió completar en un archivo la información faltante en el otro. Pero cuando la falta fue inevitable, por una parte retuve los datos de las partidas que pude conocer (para alimentar la base de datos relacionada con los actores participantes en el tráfico) y por otra parte recurrí a fuentes de sustitución para completar lo que faltaba a los totales por barco.

También hay casos, muchos, para los que no pude encontrar los registros individuales. Se trata de las fragatas-correo y de los barcos que formaron parte de la expedición de Pedro de Cevallos de 1777. Para cubrir la falta de los registros de las fragatas-correo pareció inútil dirigirse a Galicia, dado que el libro de Luis Alonso Álvarez ${ }^{21}$ explica que las copias de los registros que debían

${ }^{19}$ Las cifras recogidas en las publicaciones periódicas que utilizó Morineau surgen de los registros. Seguramente muchos colegas han utilizado sus cuadros sin leer el libro, ya que en repetidas oportunidades Morineau insiste sobre el hecho de que sus informaciones no revelan el fraude y que su principal virtud es la de ser una fuente de sustitución de los registros de navíos, que se transforma en indispensable para el periodo 1660-1720, cuando su confección no era obligatoria. Morineau, Incroyables, 1985, pp. 45-49, 221-224, 312-313, 353-354. En palabras del autor: "Les notices publiées dans les gazettes ou recueillies dans la correspondance des consuls de 1717 à 1778 sont des notices de qualité, précises dans le décompte des piastres, détaillées dans celui des marchandises. Il y a peu d'informations douteuses, et la seule, derrière laquelle on a mis un point d'interrogation se trouve hors jeu à cause de sa date : 1740. Il en résulte que dans la confrontation à entreprendre [avec les chiffres de Garcia-Baquero], les informations sur lesquelles notre travail à été bâtí ne sauraient être discréditées d'entrée, sous prétexte qu'elles seraient de moins bonne venue que les résumés conservés aujourd'hui à l'Archivo General de Indias [les relaciones]. En premier analyse, même, ils auraient dû coľncider... S'ils divergent, au total, une raison doit en être recherchée." Ibid., p. 523.

${ }^{20}$ En unos pocos casos, el registro, además de identificar a los interesados en las partidas, da detalles sobre su lugar de residencia o de avecinamiento, relaciones familiares o el origen $o$ destino de lo registrado.

${ }^{21}$ Alonso Âlvarez, Comercio, 1986, p. 20. 
encontrarse en el Archivo Histórico de Galicia desaparecieron, junto con muchos otros papeles, durante la guerra de 1808-1814. Afortunadamente encontré en el archivo de Buenos Aires un libro de la Real Renta de Correos que a todas luces es el borrador que servía de base a la elaboración de los registros que serían presentados a las autoridades. En cuanto a los navíos de la expedición de 1777, se encontró en el AGI un legajo que contiene información sobre la entrega a los destinatarios de lo que había sido transportado a bordo de dichas embarcaciones. En los dos casos, no puedo afirmar que la información obtenida corresponda a la totalidad de la carga legal, pero, a falta de otras fuentes, tuve que retener los datos que aportan.

A veces sólo se sabe que un determinado navío estaba presente en Río de la Plata en un momento dado. Se trata de casos para los que no se dispone de ningún registro ni fuente de sustitución fiable ni en Sevilla ni en Buenos Aires. Las informaciones obtenidas sobre los mismos provienen de fuentes diversas: la presentación, en tanto que testigo en un proceso, de un individuo identificado como capitán de un navío sobre el que no tenía datos; la aparición de menciones a navíos que no se incluyen en los registros de otros navios; listas elaboradas por los funcionarios donde se nombran los barcos presentes en el río; balances anuales de las reales cajas; etc. Después de haber verificado que no se trata de barcos ya conocidos pero con otro nombre traté de encontrar al menos un resumen para sus cargas de retorno. Cuando tuve la certeza de conocer al menos una parte de esa carga, la embarcación fue agregada a la base de datos. Así, quedaron seis barcos para los cuales no puedo afirmar si recibieron carga en Río de la Plata, si llegaron a zarpar y menos aún si llegaron a destino.-Habría podido atribuirles un valor promedio en metales y asignarles una determinada cantidad de cueros para hacerlos entrar en mi historia, pero preferí no ceder a la tentación de las medias. Pensé que, de todos modos, con los elementos a mi disposición podía brindar un acercamiento muy sólido del movimiento Río de la Plata-España.

Una vez que el registro de regreso estaba cerrado y cumplida la visita de salida, se entregaba al capitán del navío una copia de toda la documentación producida en Río de la Plata. Esta copia debería ser entregada al llegar a España a los oficiales de la Contratación con lo que se iniciaban las últimas etapas de la expedición (visitas, controles de descarga, etc.). En cuanto me concierne, esta última etapa gaditana me brindó la posibilidad de encontrar fuentes de control y de sustitución para los registros de navíos.

Se trata de unos extractos de los registros de regreso, establecidos por los oficiales de la Contabilidad Mayor de la Casa de la Contratación. Es un extracto y no un resumen, de los registros de tornaviaje. Era creado con la doble intención de cobrar los derechos correspondientes y de anotar la fecha en que era anulada cada una de las partidas, es decir, la fecha en que había sido entregado el contenido a los interesados, quedando el maestre liberado de su responsabilidad. 
Una vez que todas las partidas habían sido anuladas, el maestre podía iniciar el último trámite de la expedición: anular las fianzas de maestraje. ${ }^{22}$

La gran diferencia con los registros de regreso es que aquí no se informa sobre la identidad del cargador ni del propietario de la carga, sino solamente de los destinatarios. Sin embargo se está siempre ante una lista detallada de la carga y no ante un resumen, y su principal desventaja para mis objetivos es que no me permitió utilizarla para completar la base de datos en la parte relacionada con los actores, pero sirvió perfectamente para completar los registros deteriorados o ausentes en función de la obtención de los totales por barco.

\section{EL PROCESAMIENTO DE LA INFORMACIÓN Y LOS RESULTADOS OBTENIDOS}

Así, a partir de los registros de regreso y de las fuentes de sustitución, pude acumular una masa considerable de información. Para tornarla utilizable, gracias a la ayuda inestimable de Alejandro Zurdo, ${ }^{23}$ pude poseer una base de datos que reúne en unos 16700 registros todo lo que pude saber sobre las cargas de retorno de 274 navíos que partieron (o intentaron partir) con una carga conocida al menos en parte de los puertos españoles de Río de la Plata entre 1680 y 1778. Dado que los registros asumen una forma regular desde 1715 , los análisis estadísticos se refieren a dicho periodo.

Las imágenes 1 y 2 muestran las pantallas principales de la base de datos en lo relacionado con las partidas. ${ }^{24} \mathrm{~A}$ partir de allí se estructuraron diversas consultas que permitieron abordar dos tipos de problemáticas. La primera relacionada con cargas transportadas, y la segunda con los actores participantes en el tráfico. ${ }^{25}$

${ }^{22}$ El encabezado de este tipo de documentos es, con pocas variantes, el siguiente: "Extracto de las partidas que condujo registradas el navío San Pascual Baylon, su maestre Pedro Cadalso, que en 5 de septiembre arribó a este puerto [Cádiz] del de Buenos Aires adonde fue fletado por la Real Hacienda, en que se expresan las cantidades de plata y oro acuñado y labrado, frutos y demás, sujetos a quien vienen a entregar, con expresión de sus folios para la cancelación, a saber..." AGI, Contratación 2738. Extracto del registro del navío Nuestra Señora del Carmen, San Pascual Baylon y las Ánimas, 1758.

${ }^{23}$ Alejandro Zurdo construyó la primera estructura de la base de datos que me permitió dar un tratamiento informático a mis maravedíes, cueros y quintales de lana de vicuña. Sin las horas que invirtió en ese trabajo, intentando tornar posibles mis caprichos informáticos, no habría podido terminar mi investigación.

${ }^{24}$ Además de estas pantallas, hay otras destinadas a la identificación de los navios, a sus movimientos entre España y América y a recoger los datos de los registros de pasajeros.

${ }^{25}$ Más allá de las obvias que permiten recuperar los totales por barco y generales, también es posible discriminar las cargas según el tipo de envío y establecer comparaciones entre ellas. En cuanto a los actores, las consultas permiten conocer la trayectoria de cada uno de ellos, las asociaciones y extraer información de conjunto, organizándola según varios parámetros (como por ejemplo los años en que cada uno está presente en los registros y su participación proporcional en el total de cada uno de esos años). 
IMAGEN 1

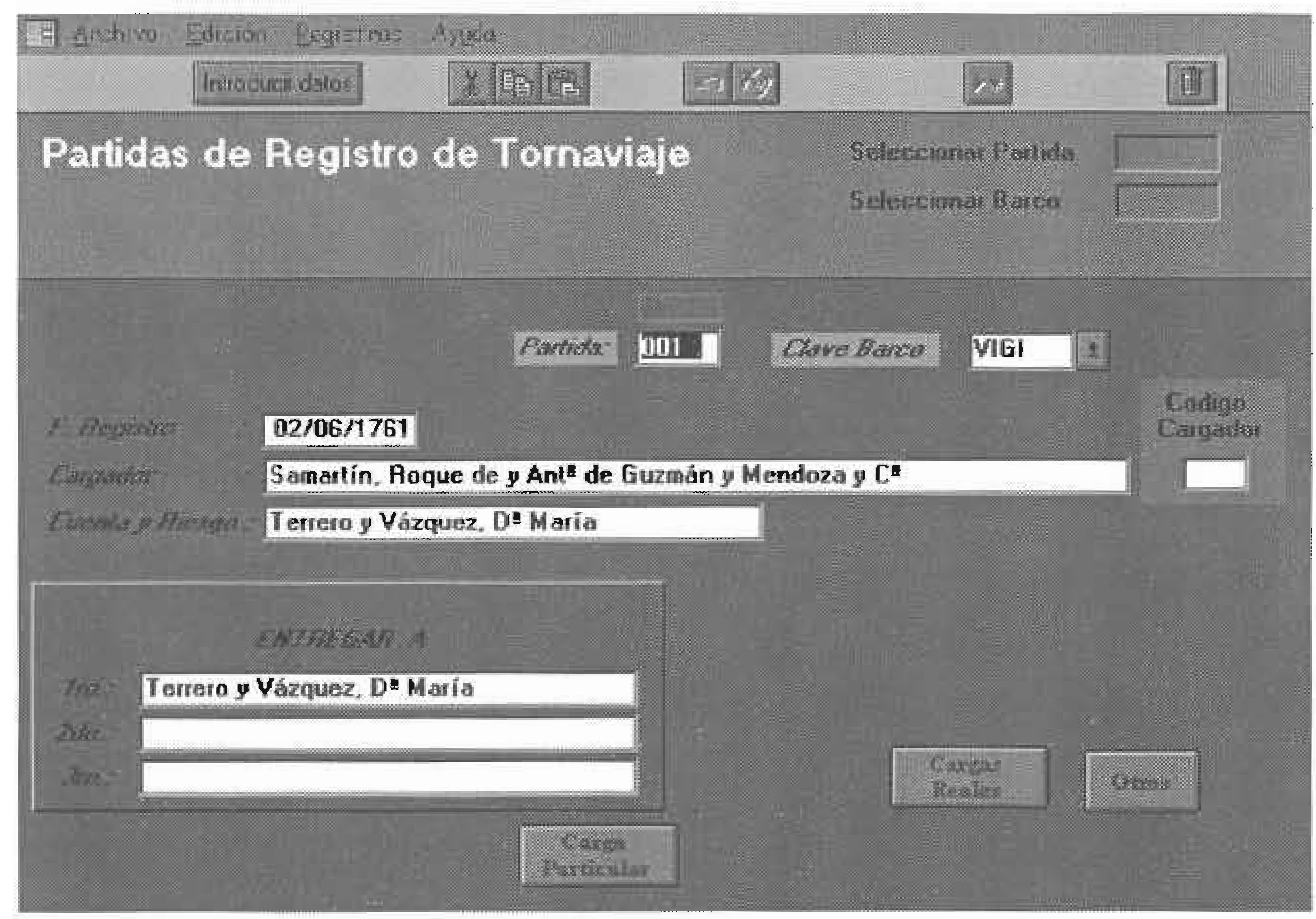

IMAGEN 2

Partidas Carga Particular CAUDALES Partida 001 Barco: VIGI

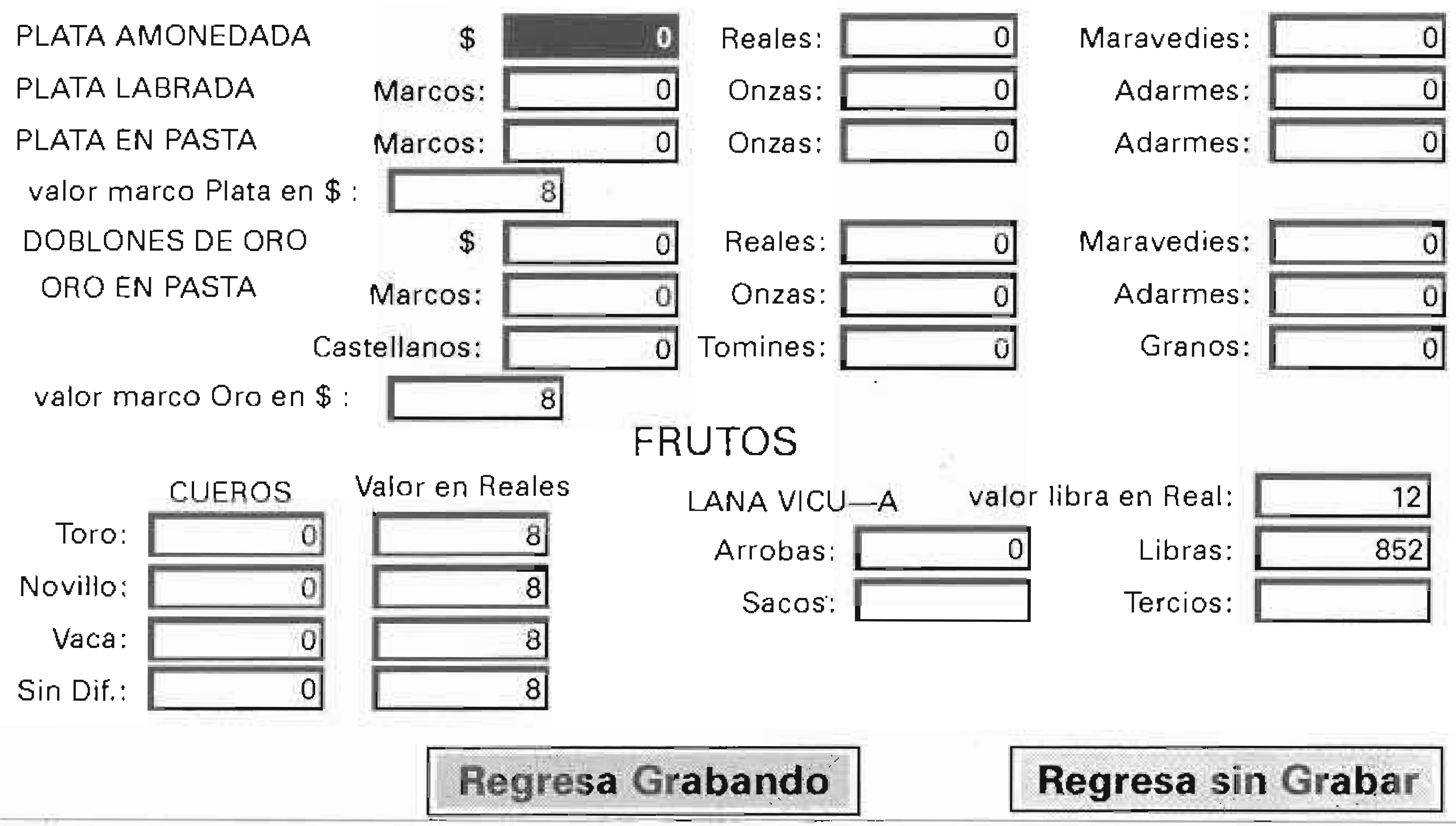


En relación con los totales generales de metales preciosos y frutos embarcados, la fuente sólo permite conocer el tráfico legal. Se sabe -y se sabía en su momento- que lo consignado en los registros no era todo lo transportado, pero luego de varios intentos por dar caza al fraude creo que se debe hacer el duelo y continuar al respecto con suposiciones y estimaciones siempre dudosas y discutibles. Las correcciones matemáticas a las cifras surgidas de los registros se revelan muy frágiles, dado que se trata de porcentajes calculados a partir de índices más o menos fortuitos aportados por fuentes muy fiables, pero que sólo se pueden aplicar a casos muy precisos: el caso del que emanan. El mundo del fraude no se lleva bien con las medias, dado que depende de muchas variables y por ello elegí no realizar extrapolaciones que habrían tenido como resultado, sin duda, aumentar mis totales. Sin embargo, ¿cómo extrapolar a más de 270 embarcaciones distribuidas en 98 años los porcentajes de fraude conocido para cuatro o cinco casos en medio de condiciones muy particulares? ${ }^{26}$ Por otra parte, no puedo dejar de tener presente que, posiblemente, el fraude podría no haber sido muy importante en los navíos de registro españoles: para ese tipo de negocios estaba enfrente Colonia del Sacramento, que suponía una notable reducción de costos y riesgos.

Además, también entre los envíos legales hay una parte que queda oculta. Se trata de libranzas y otros papeles por medio de los cuales sumas importantes podían ser movilizadas. No me fue posible entrar en ese mundo y sólo pude constatar que existe gracias a un caso en que el contenido del registro de pliegos es detallado. ${ }^{27}$

Teniendo en cuenta las prevenciones apuntadas, las cifras que obtuve deben estar precedidas con la mención "al menos..." sin que se sepa cuánto se está escapando en cada caso. El cuadro 1 presenta esas cifras. Evidentemente, esos millones son poca cosa comparados con una buena flota de Nueva España, pero lo que sería importante poder desentrañar para mí es, por ejemplo, su significado para la economía de las regiones por las cuales esos pesos circularon antes de ser embarcados. Por otra parte, esas cifras sólo reflejan el circuito

${ }^{26}$ Un naufragio, el apresamiento de un navío por enemigos, alguna correspondencia privada o de los cónsules franceses en España o Portugal... Tampoco me pareció de utilidad dedicarme a la elaboración de complicados cálculos para determinar la cantidad de cueros que podrían haber sido exportados para compararla luego con las cifras de los registros. El cálculo es posible, pero debería suponer que las embarcaciones salieron con sus bodegas y entrepuentes repletos de cueros y suponer que la oferta de cueros era abundante y permanente y que la demanda era constante.

${ }^{27}$ Se trata del registro de pliegos del navío San Juan Evangelista (1764) y en él se consigna que se envía a Domingo de Vea Murguía, quien recibió una libranza contra el Consulado de Cádiz por valor de 53144 pesos 5 reales, y que otro tanto sucedió con Pedro Ignacio Cevallos, pero por 5000 pesos, en AGI, Contratación 2743. Sobre este tipo de transferencia de fondos sólo he podido imaginar su origen: la acumulación en España de beneficios por la venta de cueros pertenecientes a comerciantes instalados en Río de la Plata y cuyo monto podría ser utilizado para saldar deudas emergentes de la compra de mercaderías o para hacer llegar a sus propietarios las partes que les correspondían por las ventas a comisión. 
legal español y, en Río de la Plata, éste dista mucho de ser el único medio por el cual bienes y metales preciosos se perdían en el Atlántico. Los cuadros 2 y 3 incorporan las cifras que pude obtener de las navegaciones inglesa y portuguesa, ambas terriblemente defectuosas y de pésima calidad en comparación con la aportada por los registros españoles. ${ }^{28}$ De todos modos se observa a simple vista que si esa información fuera mejor, se verían confirmadas las hipótesis más optimistas sobre la capacidad del mercado rioplatense para ser el pivote entre amplias regiones del sur americano y el Atlántico.

En cuanto a los actores participantes en los envíos, casi inesperadamente (mi primer objetivo al utilizar esta fuente era obtener totales por barco confiables), descubrí que las partidas de registro servirían para conocer mejor a la comunidad mercantil gracias a los datos nominales de las partidas. Básicamente, la información disponible se puede reducir a unos cuantos casos de figura:

a) Fulano carga por su cuenta y riesgo y para entregar a Mengano...

b) Fulano carga por cuenta y riesgo de y para entregar a Mengano...

c) Fulano carga por su cuenta y riesgo y para entregar a sí mismo...

d) Fulano carga por cuenta y riesgo de Mengano y para entregar a Zutano...

e) Fulano, por orden de Mengano, carga por cuenta y riesgo de éste y para entregar a Perengano...

f) Fulano, apoderado de Mengano, carga por su cuenta y riesgo y para entregar a Mengano...

g) Fulano, carga por cuenta y riesgo de Mengano y para entregar a Perengano...

Algunas otras variaciones son posibles, pero para mis objetivos aquí alcanza con las presentadas, que por otra parte son las más frecuentes. Esos registros que presenté simplificados al máximo (se omitieron las variaciones que introducirían la inclusión de informaciones relacionadas con el lugar de residencia o de vecindad de los actores, de personas físicas o morales, de conjuntos de individuos, etc.) permiten extraer un cierto número de datos.

Como punto de partida se ven aparecer al menos tres actores. En primer lugar, el cargador, aquel que se encontraba en Buenos Aires y que solicitaba el transporte a flete; luego, el propietario de lo embarcado, es decir, la persona por cuenta de quien se hace el embarque y corre con los riesgos de mar y, finalmente, el destinatario en España de la carga. Del detalle de las variaciones de la estructura de las partidas se ve que estos personajes pueden ser siempre las mismas personas o que pueden variar, lo que intenté aprovechar para obtener

\footnotetext{
${ }^{28} \mathrm{Se}$ trata de algunas fuentes fiscales españolas para la navegación inglesa y para la portuguesa de la correspondencia consular francesa, así como algunos informes de los gobernadores de Colonia del Sacramento. Desdichadamente, no he podido encontrar ni en Brasil ni en Portugal fuentes similares a los registros de navíos.
} 
algunas informaciones sobre la manera en que los comerciantes establecidos en Río de la Plata participaban en el comercio ultramarino.

Gracias a los registros es posible hacerse una primera idea de la carrera comercial de los cargadores, tratando de establecer (con la ayuda de otras fuentes) quiénes de entre ellos eran naturales o llegaron a ser residentes permanentes de Río de la Plata. ${ }^{29}$ Los registros pueden permitir ver la inserción de un individuo en el comercio ultramarino, sus caídas, desapariciones durante años y nuevos intentos. También se puede esperar ver el paso del control de los negocios de una generación a otra, o ciertas especializaciones en el campo de acción relativamente estrecho que tenían ante ellos quienes cargaban metales o frutos en los navíos. Finalmente, se puede intentar percibir un primer nivel de las redes de relaciones entre comerciantes.

Esperaba que esas carreras tuvieran un camino ascendente ideal: un individuo luego de aparecer por primera vez en tanto que cargador por cuenta y riesgo de terceros, iría sumando partidas registradas a su propia cuenta hasta que estas últimas llegasen a constituir el grueso de sus envíos. Pero no fue lo que encontré. En realidad me topé con un mundo mucho más rico que el que proponían algunos estudios de caso existentes centrados en los grandes comerciantes (la "elite de archivo") ${ }^{30}$ y sobre la base de los cuales elaboré mis primeras hipótesis de trabajo.

Ciertamente, las conclusiones a las que llegué sobre la base de las partidas de registro son muy limitadas pero reveladoras al mismo tiempo. La principal limitación es que sólo veo la participación en el comercio ultramarino, lo que hace que desaparezcan de mi lista, o que hagan tristes apariciones en ella, individuos que por otros medios sé que eran respetables comerciantes. Cada vez me convenzo más de que el comercio ultramarino no era la rama de actividad más atrayente para los comerciantes establecidos en Río de la Plata. Su as de triunfo era el control del mercado local (el complejo portuario) y las relaciones con los mercados interiores.

${ }^{29}$ Una cosa es segura, al momento de establecerse el registro, el cargador debe hallarse en Buenos Aires. Pero puede tratarse tanto de un natural de la ciudad como de un inmigrante o bien de un "comerciante golondrina", es decir, uno de los que habían llegado en un registro y sólo esperaban finalizar sus negocios para regresar a España. En más de un caso, estos últimos, después de un par de idas y venidas terminaron estableciéndose en Río de la Plata. A veces, esta fuente nos permite seguir la evolución de la propia percepción de los individuos en cuanto a su lugar de pertenencia. Así, alguien que comienza apareciendo, por ejemplo como "vecino de Cádiz y residente en Buenos Aires", al cabo de unos años aparece como "natural de Cádiz y vecino de Buenos Aires", para terminar siendo simplemente "vecino y del comercio de Buenos Aires".

${ }^{30}$ Identifico de este modo a los individuos cuyas vidas son más fáciles de seguir dado que dejaron tras de sí numerosas huellas en los archivos, pero que tal vez no sean los más representativos de la comunidad mercantil. Se trata de vidas excepcionales, que en una buena estadística deberían ser sacadas de la muestra. Ciertamente, muestran todo lo que se podía hacer, pero no lo que podían hacer todos, y el problema aparece si a partir de esas vidas de excepción elaboramos modelos interpretativos que deseamos extensibles a toda la comunidad mercantil. 
Una de las evidencias más llamativas sugeridas por las partidas de registro fue que la participación en las redes del comercio ultramarino no estaba limitada a un reducido número de grandes comerciantes que controlaban cargas, navíos $\mathrm{y}$ redes de distribución. El cuadro 4 presenta las partidas que fueron retenidas para analizar a los cargadores, y el cuadro 5 , una apretada síntesis de los resultados. De hecho, pude identificar más de 1600 individuos que actuaron como cargadores entre 1720 y 1778 , y sólo unos pocos de entre ellos responden a la figura clásica del gran comerciante. La mayoría (1 456 individuos) sólo hace apariciones esporádicas, con envíos pequeños pero que representan en conjunto cerca de $30 \%$ del total. En qué medida se trata de comerciantes o de aspirantes a comerciantes sólo lo podré decir cuando avance en el estudio de cada uno de ellos, lo que está en curso. Hasta el momento me he concentrado en el estudio de dos individuos que presentan el caso del "gran comerciante" ciante medio, siendo este último el más interesante para mí, ya que es más representativo del conjunto. ${ }^{32} \mathrm{~A}$ partir de ambos he diseñado lo que me parece podría ser un "perfil" representativo del mayor número de comerciantes presentes en Río de la Plata.

Se trataría de un comerciante principalmente volcado hacia los mercados interiores, que realiza sus compras al por mayor en Buenos Aires y que no hace demasiados esfuerzos por insertarse en el mercado ultramarino por su propia cuenta, a lo sumo ofrece sus servicios en tanto que consignatario a los comerciantes llegados en los navíos de registro. Ciertamente, ese comerciante no podía aspirar a amasar una fortuna deslumbrante en un tiempo relativamente breve, pero sí a poseer un caudal y un prestigio suficientes como para pertenecer sin lugar a dudas a la elite local, participar en la vida de la república y ser una de las voces a tener en cuenta en las cuestiones de importancia.

Sin arriesgar capital en aventuras transatlánticas, el comerciante de Río de la Plata era una de las piezas clave del circuito, y posiblemente con el tiempo la defensa de ese lugar de privilegio se convirtió en su mayor preocupación. Preocupación que lo llevó tal vez a defender la supervivencia de la "antigua constitución del reino" (es decir, el antiguo régimen cuando aún no se lo llamaba así), dado que ésta le ofrecía su más sólida defensa en contra de las modernidades que en nombre del libre comercio podrían traer como consecuencia (como lo comprobaron amargamente desde 1811 ) $^{33}$ la invasión de los mercados interiores por comerciantes venidos de lejos. Posiblemente también creyeron que parapetarse en las instituciones del antiguo régimen les iba a ofrecer una defensa ante los cambios que el poder central quería introducir en las relaciones entre la corona y América, y a ello se deba que tan tardíamente (1790) se sumerjan

31 Jumar, "Negocios", 2001.

32 Jumar, "Uno", 2003.

${ }^{33}$ En ese año el gobiemo revolucionario decreta la total libertad de comercio. 
en la empresa de la creación de un Consulado en Buenos Aires, institución tan contraria a la modernidad. Ciertamente, no se está ante empresarios ni por asomo modernos, sino ante individuos sólidamente instalados en un mundo regido por privilegios garantizados por el permanente contrabalanceo de poderes que era el antiguo régimen y en los cuales, el "montón", posiblemente encontraba satisfechas sus expectativas, que no eran sólo de índole económica, claro está.

En cuanto a las relaciones entre los comerciantes establecidos en América y en España creo que se basaban en una fuerte interdependencia. Para ambas partes resulta evidente que sin la otra no podrían tornarse efectivas las posibilidades que ofrecía Río de la Plata (o cualquier otro puerto americano) en tanto que terminal de una ruta del comercio ultramarino. Los comerciantes locales, grandes, medianos o pequeños aseguraban la venta de las cargas poniendo al servicio de sus colegas ultramarinos sus redes de distribución, determinando cuándo era posible una venta a crédito y las condiciones aplicables a cada caso en función de la solvencia y confiabilidad del solicitante, asumiendo la continuidad de las negociaciones después de que los navíos regresasen a España y remitiendo el producto de las ventas. Inclusive, si se quieren buscar relaciones desiguales, creo que habría que preguntarse si en realidad los comerciantes establecidos en España no dependían de los que estaban establecidos en América, ya que éstos detentaban la llave que daba sentido a toda la operatoria: los mercados interiores americanos. Más aún si se recuerda que en Río de la Plata los proveedores de bienes de importación no se limitaban a los comerciantes llegados en los navíos de registro. Un comerciante porteño sólo necesitaba comprar una reducida cantidad de bienes del circuito legal para poder así mantener una pulpería, tienda o almacén que bien podrían estar mayoritariamente provistos por bienes de contrabando desde Colonia del Sacramento, por ejemplo. Recordemos que sin comercio legal es imposible el ilegal, pero las proporciones entre uno y otro, cuando el contrabando está tan arraigado como en Río de la Plata, ${ }^{34}$ seguramente favorecían a este último.

Pues bien, independientemente de los resultados obtenidos o de la lectura que yo haya hecho de los mismos (siempre discutible, siempre objetable) creo haber demostrado al menos que es posible realizar estudios relacionados con el comercio ultramarino pero con el punto de vista centrado en América. Calculo que si se emprenden estudios similares para cada puerto (o complejo portuario) americano podremos llegar en algún momento a comprender mejor la historia

${ }^{34}$ La presencia portuguesa en la Banda Oriental permitió la aparición del crédito y de las relaciones de larga duración en el circuito ilegal, lo que contribuyó a que éste fuera accesible para todos aquellos que querían incursionar en el comercio (sólo era necesario trabar relaciones de confianza con un comerciante de Colonia del Sacramento) y despojó al comercio ilegal de su carácter esporádico, dependiente de, por ejemplo, la llegada de navíos que solicitaban una arribada forzosa (maliciosa) cuando las operaciones se debían saldar de contado, reduciendo el número de participantes. 
de esas sociedades surgidas en función de la creación de riquezas que tarde o temprano saldrían del continente. Los registros de navíos constituyen una excelente puerta de entrada a ese mundo, sólo hace falta la paciencia necesaria para robarles sus secretos.

CUADRO 1. RESUMEN GENERAL DE LAS EXPORTACIONES DE RÍO DE LA PLATA. CIRCUITO ESPAÑOL. PARTICULARES Y REAL HACIENDA, 1715-1778. EN PESOS DE 8 REALES

\begin{tabular}{lrrr}
\hline Metales preciosos & Cuentas particulares & Real Hacienda & \multicolumn{1}{c}{ Total } \\
Plata & & & \\
$\quad$ amonedada & 40301395.518 & 2990360.938 & 43291756.456 \\
$\quad$ labrada & 773055.188 & 88207.705 & 861262.938 \\
$\quad$ en pasta & 263756.188 & 3791.875 & 267548.063 \\
Subtotal plata & 41338206.893 & 3082360.563 & 44420567.456 \\
Oro & & & \\
$\quad$ amonedado & 4704279.982 & 3388.000 & 4708667.982 \\
$\quad$ en pasta y labrado & 1383538.180 & 1600.000 & 1385138.180 \\
Subtotal oro & 6087818.162 & 5988.000 & 6093806.162 \\
$\quad$ & & & \\
Subtotal metales & 47426025.055 & 3088348.563 & 50514373.618 \\
& & & \\
Producciones americanas & 5641993.500 & 92989.750 & 5734983.250 \\
$\quad$ cueros & 776488.125 & 22132.500 & 798620.625 \\
$\quad$ lana de vicuna & & 505120.000 & 994467.360 \\
$\quad$ otros & 489347.360 & 620242.250 & 7528071.235 \\
Subtotal productos & 6907628.985 & & \\
$\quad$ americanos & & 3708590.813 & 58042445.853 \\
Total & 54333854.040 & & \\
\hline
\end{tabular}

Fuente: Jumar, Commerce, 2002. 
CUADRO 2. METALES PRECIOSOS (EN PESOS DE A 8 REALES)

EXPORTADOS. NAVEGACIÓN ESPAÑOLA, INGLESA Y PORTUGUESA. 1716-1778

\begin{tabular}{|c|c|c|c|c|}
\hline Periodo & $\begin{array}{l}\text { Navegación } \\
\text { española }\end{array}$ & $\begin{array}{l}\text { South Sea } \\
\text { Company }\end{array}$ & $\begin{array}{l}\text { Navegación } \\
\text { portuguesa }\end{array}$ & $\begin{array}{l}\text { Total } \\
\text { pesos }\end{array}$ \\
\hline \multicolumn{5}{|l|}{$1716-1718$} \\
\hline $1719-1721$ & 1742035 & & & 1742035 \\
\hline $1722-1724$ & & 84500 & 3000000 & 3084500 \\
\hline $1725-1727$ & 739512 & & & 739512 \\
\hline $1728-1730$ & 20992 & & & 20992 \\
\hline $1731-1733$ & 1144243 & 60158 & 88311 & 1292712 \\
\hline $1734-1736$ & & 322000 & & 322000 \\
\hline $1737-1739$ & 1749559 & 189341 & & 1938900 \\
\hline $1740-1742$ & 2660 & & 200000 & 202660 \\
\hline $1743-1745$ & 1656721 & & & 1656721 \\
\hline $1746-1748$ & 844155 & & 9188275 & 10032430 \\
\hline $1749-1751$ & 3378294 & & 1522000 & 4900294 \\
\hline $1752-1754$ & 4239487 & & 214285 & 4453772 \\
\hline $1752-1757$ & 4310253 & & 146664 & 4456917 \\
\hline $1758-1760$ & 2948127 & & 700000 & 3648127 \\
\hline $1761-1763$ & 1754147 & & 2000000 & 3754147 \\
\hline $1764-1766$ & 5373670 & & 800000 & 6173670 \\
\hline $1767-1769$ & 4018845 & & 146000 & 4164845 \\
\hline $1770-1772$ & 5453372 & & & 5453372 \\
\hline $1773-1775$ & 4661206 & & & 4661206 \\
\hline $1776-1778$ & 6477088 & & & 6477088 \\
\hline Total & 50514373 & 655999 & 18005535 & 69175900 \\
\hline
\end{tabular}

Fuente: Jumar, Commerce, 2002. 
CUADRO 3. CUEROS (EN UNIDADES) EXPORTADOS NAVEGACIÓN ESPAÑOLA, INGLESA Y PORTUGUESA. 1716-1778

\begin{tabular}{|c|c|c|c|c|}
\hline Periodo & $\begin{array}{c}\text { Navegación } \\
\text { española }\end{array}$ & $\begin{array}{l}\text { South Sea } \\
\text { Company }\end{array}$ & $\begin{array}{l}\text { Navegación } \\
\text { portuguesa }\end{array}$ & $\begin{array}{c}\text { Total } \\
\text { unidades }\end{array}$ \\
\hline $1716-1718$ & 5300 & 109013 & & 114313 \\
\hline $1719-1721$ & 24266 & 5000 & 19750 & 49016 \\
\hline $1722-1724$ & & 76882 & 213440 & 290122 \\
\hline $1725-1727$ & 31076 & 81046 & 213439 & 325561 \\
\hline $1728-1730$ & 6252 & 20971 & 148019 & 175242 \\
\hline $1731-1733$ & 30440 & 35500 & 321290 & 387230 \\
\hline $1734-1736$ & & 5918 & 39665 & 45583 \\
\hline $1737-1739$ & 36036 & 18700 & & 54736 \\
\hline \multicolumn{5}{|l|}{$1740-1742$} \\
\hline $1743-1745$ & 74002 & & & 74002 \\
\hline $1746-1748$ & 36011 & & 80000 & 116011 \\
\hline $1749-1751$ & 175622 & & & 175822 \\
\hline $1752-1754$ & 138664 & & & 138664 \\
\hline $1752-1757$ & 186737 & & & 186737 \\
\hline $1758-1760$ & 108553 & & 96000 & 204553 \\
\hline $1761-1763$ & 92510 & & & 92510 \\
\hline 1764-1766 & 213080 & & & 213080 \\
\hline $1767-1769$ & 271298 & & & 271298 \\
\hline $1770-1772$ & 512740 & & & 512740 \\
\hline $1773-1775$ & 686714 & & 19630 & 706344 \\
\hline $1776-1778$ & 678741 & & & 678741 \\
\hline Total & 3308242 & 352830 & 1151233 & 4812305 \\
\hline
\end{tabular}

Fuente: Jumar, Commerce, 2002. 


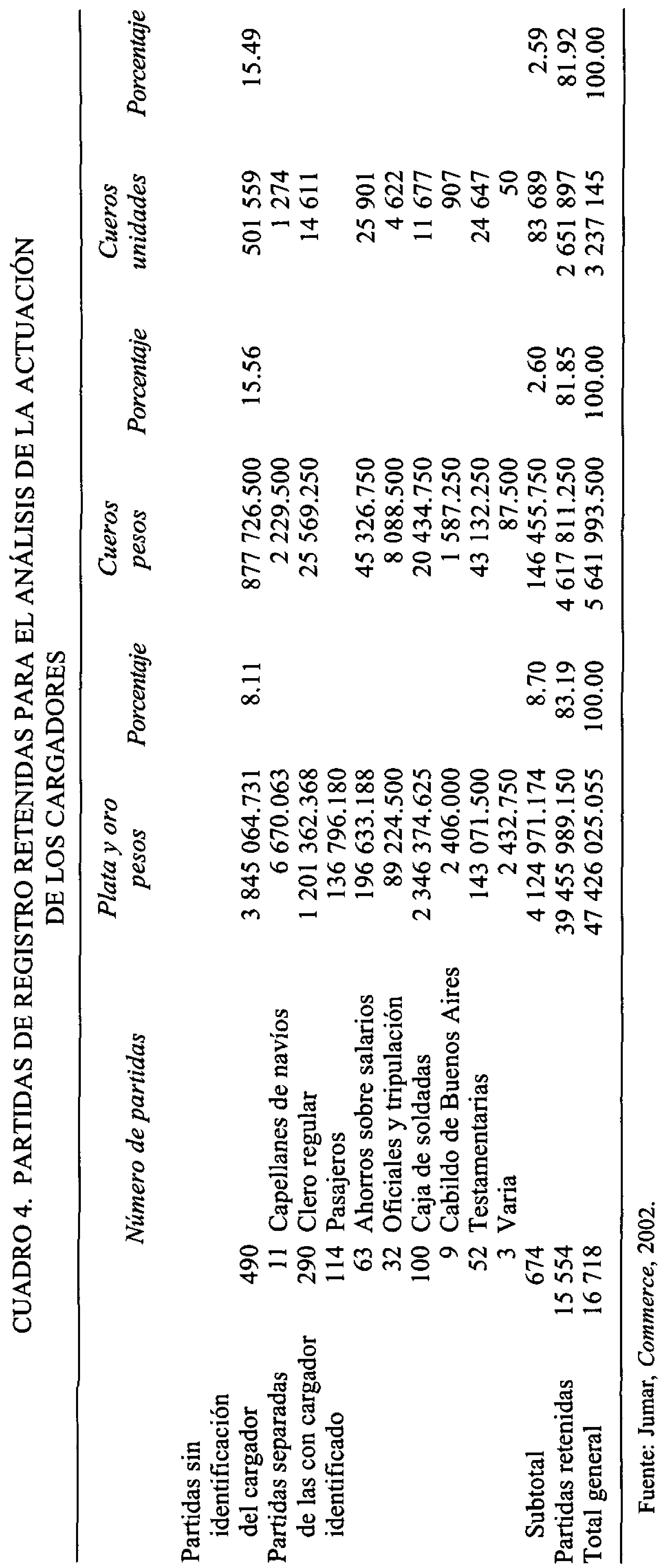




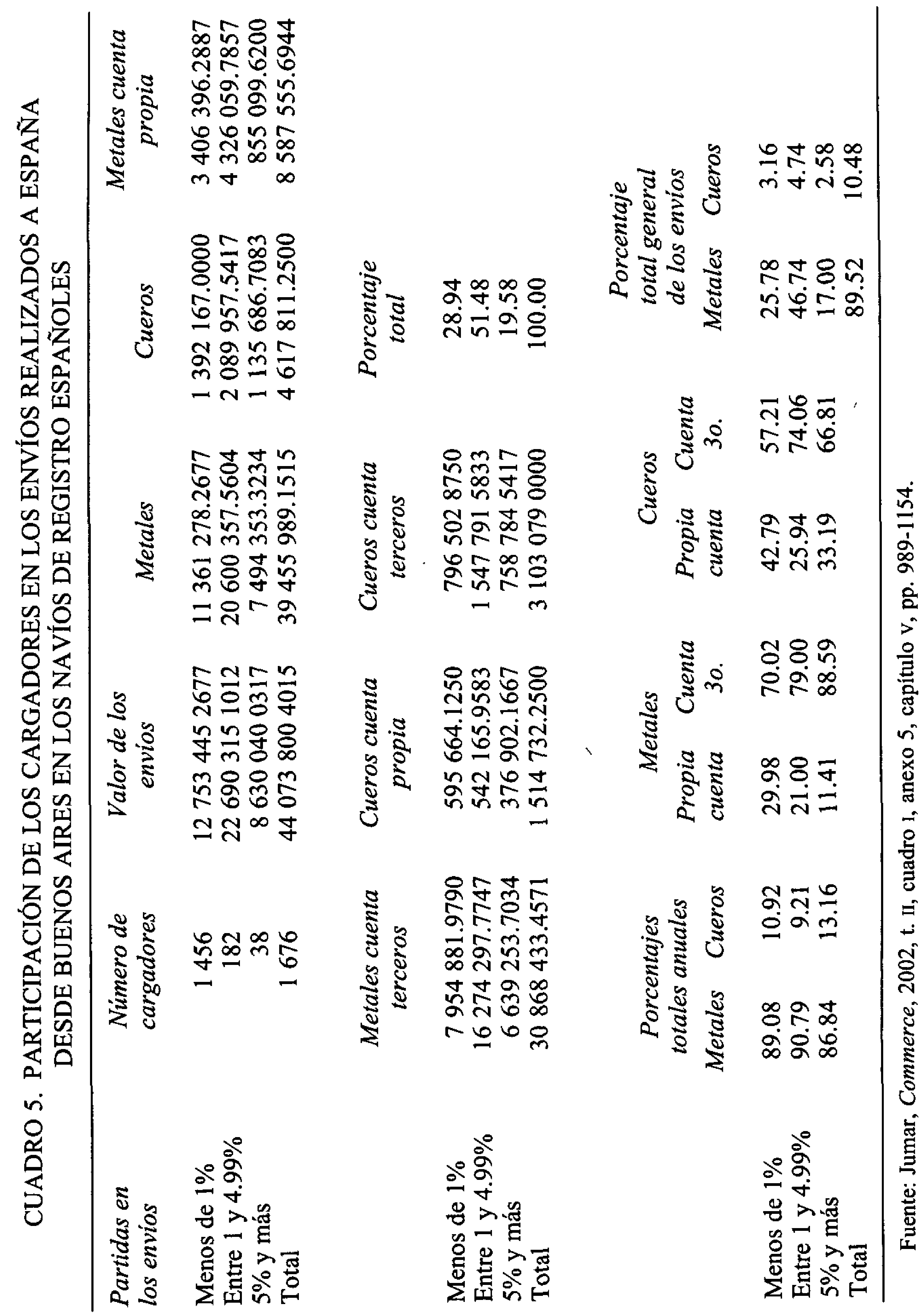




\section{ARCHIVOS}

AGI Archivo General de Indias, Sevilla, España

AGN Archivo General de la Nación, Buenos Aires, Argentina

\section{BIBLIOGRAFIA}

Alonso Álvarez, LuIs, Comercio colonial y crisis del antiguo régimen en Galicia (17781818), La Coruna, Xunta de Galicia-Consellería da Presidiencia, 1986.

APOlant, JuAN AlejandRo, Crónica del naufragio del navio Nuestra Señora de la Luz (Montevideo 1752), Montevideo, Centro de Estudios del Pasado Uruguayo, 1968.

Arazola Corvera, María Jesús, Hombres, barcos y comercio de la ruta Cádiz-Buenos Aires (1737-1757), Sevilla, Diputación de Sevilla, 1998.

GARCíA-BAQUERo GONZÁleZ, ANTONIO, Cádiz y el Atlántico (1717-1778). El comercio colonial bajo el monopolio gaditano, Sevilla, Escuela de Estudios Hispano-Americanos, 1976, 2 tt.

"Las remesas de metales preciosos americanos en el siglo XVIII: una aritmética controvertida", Hispania, LVI/1, 192, 1996, pp. 203-266.

GARDNER SORSBY, VICTORIA, "British Trade with Spanish America under the Asiento, 17131740", tesis de doctorado, Londres, University of London, 1975.

JUMAR, FERNANDO, "Negocios en red. Los Basavilbaso. Mediados del siglo XVIII", VIII Jornadas Ínter-escuelas y Departamentos de Historia, mesa temática "Familia y sociedad en el Río de la Plata, 1750-1850", Salta, Argentina, 19 al 22 de septiembre de 2001.

Le commerce atlantique au Río de la Plata, 1680-1778, Villeneuve d'Ascq, Francia, Presses Universitaires du Septentrion, 2002, 2 tt.

"Uno del montón. Juan de Eguía, vecino y del comercio de Buenos Aires. Siglo XVIII", III Jornadas de Historia Económica, Asociación Uruguaya de Historia Económica, simposio Comercio y Comerciantes, el Río de la Plata Durante el Siglo XVIII, Montevideo, 9 al 11 de julio de 2003.

Malamud Rikles, Carlos, Cádiz y Saint Malo en el comercio colonial peruano (16981725), Cádiz, Diputación Provincial, 1986.

MORINEAU, MICHEL, Incroyables gazettes et fabuleux métaux. Les retours des trésors américains d'après les gazettes hollandaises (XVT'-XVIII siècles), París-Londres, Éditions de la Maison des Sciences de l'Homme/Cambridge University Press, 1985.

MOUTOUKIAS, ZACARÍAS, "Le Río de la Plata et l'espace péruvien au XVII siècle: commerce et contrebande par Buenos Aires", tesis de doctorado, París, École des Hautes Études en Sciences Sociales, 1983 (existe una versión publicada en castellano: Buenos Aires, Centro Editor de América Latina, 1988).

, "El crecimiento en una economía colonial de antiguo régimen: reformismo y sector externo en Río de la Plata (1760-1796)", Arquivos, Lisboa, Fundação Calouste Gulbenkian, 1996, pp. 771-813.

TORRe Revello, José, "Los Navíos de Registro en el Río de la Plata. 1500-1700”, Boletín de la Academia Nacional de la Historia, vol. XxxIv, 1963, Buenos Aires. 


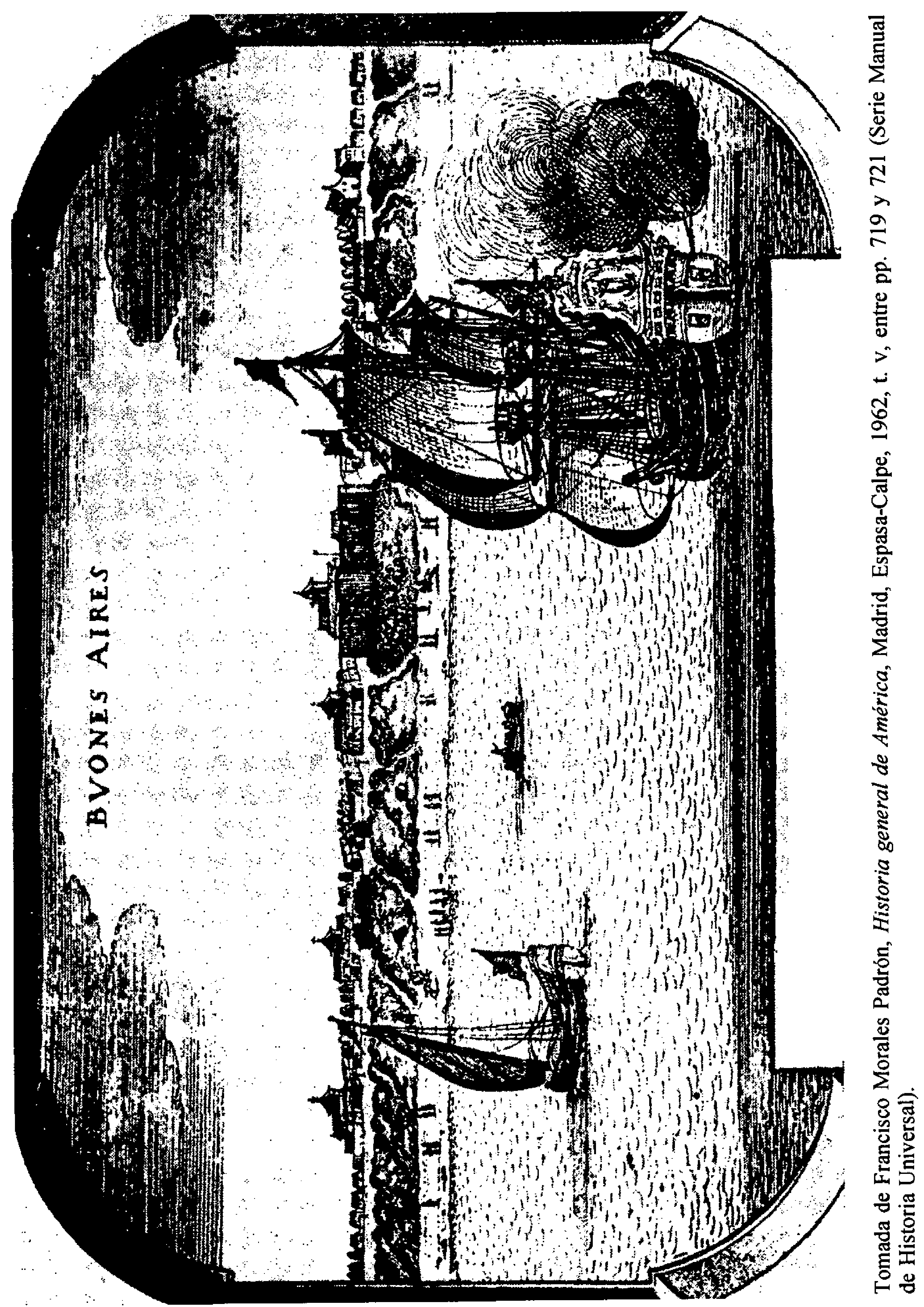

